\title{
Geoprocessing of Grand Parks in Dubai: Managing Wellbeing from the Urban Public Spaces to the Leisure and Sport Environments
}

\author{
Leonardo Jose Mataruna-Dos-Santos ${ }^{1,2,6, *}$, Mohamed Ahmed Hamed Mahmoud Sayed Ahmed \\ Abdelwahab Al Shibini ${ }^{3}$, Jaume Cazorla Milla ${ }^{4}$ and Asli Cazorla Milla ${ }^{5,6}$. \\ 1 Canadian University of Dubai, leonardo.mataruna@cud.ac.ae \\ 2 Coventry University, CTPSR; 1.mataruna@coventry.ac.uk \\ 3 American University in the Emirates; 182230004@aue.ae \\ 4 Universidad de Salamanca, jaume.cazorla@usal.es \\ 5 American University in the Emirates, asli.milla@aue.ae \\ 6 Universidade Federal do Rio de Janeiro, PACC, \\ * Correspondence: leonardo.mataruna@cud.ac.ae
}

\begin{abstract}
The aim of this paper is to analyze the five grand parks in Dubai, United Arab Emirates (UAE) and provide a geoprocessing approach to different aspects such as sport, health, leisure, recreation, and public wellbeing. The study uses a hybrid of qualitative and quantitative approach as methodology. Sustainability offerings, accessibility for people of determination and special needs, typology and the geolocations of the grand parks plays crucial role in residents' wellbeing. The paper concludes with recommendations for Dubai government to design new and innovative approaches to manage wellbeing of urban public places into the leisure environment for residents.
\end{abstract}

Keywords: GIS; urban design; Dubai and public health

\section{Introduction}

Dubai is an emirate located in the United Arab Emirates (UAE) which is considered as an innovative, upbeat and modern city nowadays. The city primarily focuses on general business activities as well as conducting several innovative projects. Most people that move to Dubai do so for the purpose of finding better job opportunities in order to earn a decent salary, and to gain an improved standard of living. During a period of roughly 50 years, the status of Dubai has changed remarkably, and changes in the city's economic, cultural, political and social factors have been noticed clearly as well as changes in the nature of the urban development (Pacione, 2005; Davidson, 2019). Dubai diversified in the 1990s and began developing their tourism status, real estate industry, and their financial sectors. The city showed the world their status in being a city that constantly develops by building remarkable buildings and projects ever since such as Burj Khalifa, Palm Jumeirah, Dubai Mall, and Burj Al Arab and are waiting to host the Expo in 2021 as it was postponed due to Covid19, as well as many other projects in the future (Visit Dubai, 2020; Davidson, 2019). In 2006 Sheikh Mohammed Bin Rashid Al Maktoum became the ruler of Dubai. Which contributed a lot to the thriving and development of Dubai ever since. Nowadays, Dubai is considered as the entertainment capital of the Middle East as it is the most place to thrive in the region and acquire diverse tourists from all over the world. Nevertheless, Islamic beliefs and rules are still applied in the city despite the diverse economy (Dubai.com, 2020). Dubai has managed to host a number of events which in result boosted their economy and their image as a tourist destination. Events include both sporting events and entertainment events, the most popular annual sporting events include the Dubai World Cup for horses and the annual ATP Tennis Championship. Entertainment events include weekly concerts 
during the period of which the Global Village is open, also other several events such as the Art Dubai Fair, Dubai museum, and many others (Global Village, 2020; Davisdon, 2019).

As in every place around the world, the door for improvement is always open, as a result in an emirate such as Dubai developing is key in order to sustain the position of the city. Therefore, one of the factors in which Dubai could improve includes offering more parks to the community. Parks are one of the best contemporary ways in which people could visit to participate in sports activities as well as engage in many recreational and leisure activities. Furthermore, the availability of parks in a country holds within countless benefits for all stakeholders involved, whether they are park visitors or even the entire country as a whole. For example, in some cases when families decide to move from one place to another, one of the main resources the family would like to have is the availability of a close park in which they can all visit as a family as well as to have a safe and secure place where young children can visit to play and meet friends. As a result, it is vital to include the availability of parks in every single neighborhood in every country all over the world. During February 2020 the Coronavirus (Covid-19) pandemic began to severely affect the UAE as it affected the entire globe, which resulted in the closing down of schools, workplaces, sports facilities, museums, malls, cinemas, masjids, parks, swimming pools, gyms, as well as postponing all the events that were due to be held in the country. (Ammar et.al, 2020). Moreover, for a while people were not allowed to leave their homes unless they get an online permit, and in the case of leaving homes, people were required to wear gloves as well as masks. Furthermore, if anyone was caught violating any of the rules, severe fines were issued to them. In other words, the country was in complete lockdown. This was all due to the fact that Covid-19 has no specific vaccine and that it spreads easily by small droplets resulting from an infected person. The droplets could be inhaled if they stay in the air, the droplets could land on a specific surface which could be touched by another person, or through contaminated hands. However, constantly washing hands, staying at home, and maintaining social distancing could protect individuals from getting infected by the virus (Dubai Health Authority, 2020; UAE Ministry of Health \& Prevention, 2020; WHO, 2020e).

As all around the globe, life will return as a new "normal" style in the UAE society as restrictions slowly began to ease and many places began to reopen. Furthermore, all the parks need to be ready in order to be used as well as to make life more enjoyable in Dubai after the lockdown. Therefore, appropriate measures should be undertaken in all parks that include providing specific places for washing hands or sanitizing them, establishing the rule of social distancing in the parks at least until the situation becomes better, and the parks are required to provide visitors with wet wipes, sanitizers, gloves, masks, and any other necessary equipment that is used in order to limit spreading of the virus. This research aims at answering the following question: Can Dubai's grand parks become more active by offering sport and recreational facilities and programs that can adapt with the new policies after Covid-19, for residents with different ages?

\subsection{Sport Governing Bodies in the UAE}

In order to have an efficient and effective system for sport development in a particular country, good governance and governing bodies are integral to achieve such a goal. Specific rules, policies, and regulations should be established by the governing bodies as well. Similarly, when having several sport governing bodies working together in a collaborative manner in order to enhance the sport sector in a particular country is more beneficial than having one sport governing body working in an independent manner (Shilbury, O'Boyle, \& Ferkins, 2016; Yeh \& Taylor, 2011). There are numerous sport governing bodies that are responsible for the various different sports in the UAE. These governing bodies serve as bodies that establishes rules, regulations and policies in order for the sports to be held out and represented in their appropriate manner. However, all the sport governing bodies in the UAE are considered under provision from the General Authority for Sports as they are responsible for the development of the sport sector in the UAE as well as to look after all the different sport governing bodies in the country (General Authority of Sports, 2020; UAE Government, 2019). Moreover, all the sport governing bodies thrive to achieve the goal of developing and spreading sport as much as they can so that it would be recognized as part of the UAE culture, 
and to be considered as a way of life in the UAE to further develop the country and reach worldwide status. Some of the sport governing bodies existing in the UAE under the General Authority for Sports include the sports councils existing in Abu Dhabi, Dubai, and Sharjah, also the Automobile and Touring Club of the UAE (ATCUAE), Emirates Cricket Board, Emirates Diving Association, Emirates Equestrian Federation, Emirates Golf Federation, Emirates Motor Sports Federation, Emirates Racing Authority, Higher Education Sports Federation, National Olympic Committee, and the United Arab Emirates Football Association (UAEFA) (General Authority of Sports, 2020; UAE Government, 2019).

\subsection{Vision of Sport in $U A E$}

Identifying a vision and a mission is an essential part of having a strategic path in order to reach the goals and objectives that are determined. Similarly, having a long-term process in any area is integral to identify key outcomes desired. The UAE is an example of a country that always identifies their desired outcomes from a specific period of time. As they set out visions for the country in 2021 and have already identified what they need to achieve before 2071 (UAE Government, 2020; Papulova, 2014).

Table 1. UAE Sport Vision.

\begin{tabular}{|c|c|}
\hline Vision of Sport 2021 & Vision of Sport 2071 \\
\hline $\begin{array}{l}\text { "The } 2021 \text { vision of the UAE regarding sport is to } \\
\text { achieve a cohesive society and a preserved identity } \\
\text { as this is one of the six pillars in the National }\end{array}$ & $\begin{array}{l}\text { "In an attempt to ensure the development and } \\
\text { satisfaction of all the upcoming generations of the } \\
\text { UAE, Sheikh Mohammed Bin Zayed Al Nahyan } \\
\text { crown prince of Abu Dhabi identified that one of the }\end{array}$ \\
\hline $\begin{array}{l}\text { Agenda of the } 2021 \text { vision, moreover, the UAE will } \\
\text { use the number of their medals during the Olympic }\end{array}$ & $\begin{array}{l}\text { key pillars in the UAE } 2071 \text { vision is not only to } \\
\text { educate individuals to have a positive and healthy }\end{array}$ \\
\hline $\begin{array}{c}\text { Games and the Paralympic Games as one of the Key } \\
\text { Performance Indicators (KPI) of the degree of } \\
\text { success regarding this aspect in the National } \\
\text { Agenda" (UAE Government, 2019). }\end{array}$ & $\begin{array}{l}\text { lifestyle, but also obtaining a happy and cohesive } \\
\text { community for many generations, moreover the } \\
\text { UAE is focusing on investing in advanced } \\
\text { technologies in order to have the society properly } \\
\text { educated and informed" (UAE Government, 2020). }\end{array}$ \\
\hline
\end{tabular}

Source: Adopted from UAE Government (2019; 2020).

\subsection{Parks in Dubai}

Dubai Municipality has 145 parks under their provision as per 2019, and they are divided into 5 grand parks, 66 district parks, 5 lake parks, 67 public areas, and 2 specialty gardens (Dubai Municipality, 2020b). The geoprocessing and further analysis of the official parks were tested. The sample was composed by the 5 grand parks under the provision of Dubai Municipality (Dubai Municipality, 2020a), which are: Al Safa Park, Al Mamzar Beach Park, Mushrif Park, Zabeel Park, and Creek Park. The park was stablished in 1974 - Mushrif Park; 1975 - Al Mamzar Beach Park; 1994 - Al Safa Park and Creek Park; and in 2005 - Zabeel Park. (Dubai Municipality, 2020b).

\section{Literature review}

\subsection{Parks Management}

Public space is one of the many aspects that can be evolved and developed in cities. If cities acquire a huge number of diverse nations and cultures (such as Dubai) then these public spaces are key to create a sense of coming together from the community as a whole, as in these spaces they will meet and encounter each other. Likewise, public space should be developed and beautified for the residents on a regular basis. Not just for the purpose of showing the country in a good image for foreigners and tourists, as it was the case during the 2012 London Olympic Games. Several residents in Stratford, United Kingdom, started noticing beatifications when the Olympic Games' date to start came close. Which resulted in the fact that the beautification and development of the city was not produced for the local residents, but it was undertaken for the reasons to showcase the United Kingdom as a developed country as a whole. However, it was later indicated that one of the key 
objectives of London was to create a positive long lasting development legacy in East London specifically for the sake of obtaining many benefits as well as benefiting the local community in that area. Other cities that have further took on the task of improving their public spaces that they acquire include Berlin, Birmingham, and Barcelona (Raco, 2014; Smets \& Watt, 2013; Kennelly \& Watt, 2013; Madanipour, 1999).

Another key thing to remember is that parks are well known to be an exemplary place for engaging in physical activity. Parks offer a number of options to choose from in order to engage in physical activity, such as walking and jogging trails, different fields for group sports, fields for individual sports, gymnasiums, children's playgrounds, and other activities as well. Nevertheless, there are several key aspects to consider in order to attract people to a park, as people have different tastes and preferences. Size of the park may influence the number of people going to the park. Moreover, accessibility is integral for the community, and that includes everyone especially the people of determination. Other key aspects to consider include the availability of the park such as the working hours of the park, and quality of the services as well as facilities offered in the park (Evenson et al, 2013; Cohen et al, 2007; Bedimo-Rung, Mowen, \& Cohen, 2005).

Specific standards that provide accessibility for different segments in communities should always be implemented, in order to attract people to a certain park for the reason of which the services offered are easily accessible and are carefully planned. Jansson and Persson (2010), mentioned that in Sweden, multiple parks use the standard of providing the small kids' playground 50 meters away from the entry door of the park, and the more equipped elements (areas that obtain obstacles needing more skills) are located 150 meters away from the entrance. Such standards have been commenced in order to show that careful planning has been undertaken, in order to provide accessible and easily achievable playgrounds in the parks. Therefore, if parks all over the world would put such planning in their standards for all the segments in the communities surrounding them, overall satisfaction of all these segments will be achieved, and many people would enjoy visiting the parks (Jansson \& Persson, 2010). Furthermore, it is worth mentioning that all modern nations should recognize parks and recreation services as an integral role that serves the nation positively in many ways. These particular services should be offered and regularly developed by municipalities, counties, states or special park and recreation sectors. Various development strategies should always be applied a in regular manner by the governing bodies that are responsible for the parks in the country, in order to attract tourists as well as local residents for a long period of time and keep them engaged in the parks. One way that could be implemented to receive feedback about what sorts of development are required is by taking the opinions of local communities surrounding the park. In this way park developers could satisfy their desires and make sure they are satisfied about the products or services offered. However, this does not mean taking feedback from one segment from the society, but different segments should be asked to satisfy all wants and needs. For example, in terms of developing a children's playground, developers should ask children about their opinions, and take feedback from them as this strategy could be a way of improving playing for children in the park (Jansson, 2013; Godbey et al, 2005). The same concept of collecting opinions should be applied with people of determination, people with mobility limitations, elderly people, and women in maternal condition (pregnant or having baby strollers).

According to More (2005), a particular type of management style regarding parks includes handing it to be fully functioned by the government. Notwithstanding, funding could be provided from taxes and other alternative sources. Moreover, decision making regarding the parks would be primarily from the government, but the inclusion of public opinion can also be present. Besides, decisions that are environmentally friendly can be implemented in the public spaces or areas of land used for recreation. However, it is true that non-users of the parks would also be paying taxes for it, but the public areas would always be available for use with either minimum cost or no cost whatsoever, and they can access it anytime in the near future. Not to mention, that overall parks have to be developed and urbanized in all cities in a particular country. Banerjee (2001), cited an example that in the United States of America it is well noticed that richer states have advanced, innovative, and cutting-edge services in their parks which as a result encourages the surrounding community to use these parks. However, less fortunate cities do not acquire the opportunity to have all these latest 
and greatest new facilities and services to offer their surrounding community, which as a result leads to the fact that public spirit and motivation regarding visiting public parks in these less fortunate areas is low compared to the wealthier states (More, 2005; Banerjee, 2001).

\subsection{Conceptualizing Sport Management in the Park Sector}

Sports management is regarded as a new field in the UAE especially in the parks and recreation sector. Therefore, there is a wide door opened in terms of implementing numerous new innovative and creative methods that would help improve not only the parks and recreation sector, but also the sports sector. Accessibility is referred to the extent of which a place or service can be reached or taken. Nicholls (2001) explains that Geographic Information Systems (GIS) is a tool used for measuring the levels of which accessibility is present in a specific geographical location, such as parks. Usually, a GIS contains numerous data about the geographical area which is both quantitative as well as qualitative. For instance, in the case of analyzing a park, the data collected by the GIS would include the size of the entire park, number of sport courts or fields, number of parking spaces available, length combined with width of many spaces, degree of which natural resources are present, and much more extensive as well as detailed information. There are many benefits derived from utilizing GIS, some of the benefits include providing managers with countless opportunities that they can use to improve aspects in their planning, managing facilities in the geographic location efficiently and effectively, as well as accumulating information in one organized virtual screen in which the data analyzer can try examining different scenarios to observe what can be the results of these situations. Therefore, several policy developers and decision makers have prompted to use GIS whenever they intend to take any decision, due to the GIS's ease of use and speed of providing results. It is required to develop suitable strategies to make sure that these facilities will be used more in the future and not squandered (Nicholls, 2001).

In other words, GIS allows the planners to overlay various information about a specific geographical area in an organized manner that could be communicated and received simply by several stakeholders. Therefore, it is safe to say that GIS aids and guides planners of wide geographical ranges by offering them integration, communication, and representation of countless data regarding the geographical site (Muyphy \& King, 2013 as cited in Lahoti et al, 2019). For this study six elements were selected to be analyzed relating to availability and usability, they include sports, health, leisure, recreation, policies, and facilities management. Firstly, according to Parry (2019), in order to classify something as a sport there are six special criteria that are obligated to be present, which are the actions should be human activities, physical aspects should be present, a specific set of skills are required to be utilized, there should be a sense of competition, governing bodies to establish rules should be present, and finally national or international institutions should be existing (Parry, 2019). Another study conducted by Mitchel et al (2005) states that the classification of sports depends on a few factors, and they mainly include the type as well as the intensity of the exercise done in the particular sport. It is worth mentioning that there are two types of exercise, which are dynamic and static. Dynamic exercise includes the changing in muscle length as well as moving the joints with some sort of a rhythm, for instance, distance running. On the other hand, static exercise does not include changing in the muscle length or moving the joints, but can include moving the joints as minimal as possible, for example, water skiing (Mitchell et al, 2005).

It is widely agreed on that sports have the power to spread peacefulness, cohesivity, and equality among different societies and communities. In simpler terms, sports is a well identified tool for achieving different kinds of development (Spaaij, 2009). Secondly, health can be improved by many factors, but physical activity is one of the best aspects to engage in for a healthier lifestyle. Moreover, regular exercising can benefit the health by boosting the immune system to fight many diseases. However, not being physically active can lead to many diseases which include obesity, depression, diabetes, joint and bone diseases, cardiovascular diseases, and many more (Janssen \& LeBlanc ,2010; Warburton, Nicol, \& Bredin, 2006).

A key thing to remember is that not only physical activity can aid one's health, but also it can help maintain a healthy lifestyle for the long term. As many studies indicated that regular physical 
activity fights diseases that get developed when not exercising in a consistent manner Engaging in leisure activities such as playing board games, reading, or even sports, can reduce the risk of obtaining mental illnesses such as dementia or Alzheimer's (Verghese et. al, 2003). Moreover, leisure activities have a wide range in which it can be consumed which includes not only competitive sporting activities, but also simpler activities such as watching television (Mahoney \& Stattin, 2000). Furthermore, leisure activities can provide individuals performing it with several opportunities to achieve needs as well as life values. Leisure activities provide people with several benefits such as building social relationships with others, gaining various skills and abilities, and feeling positive emotions. Therefore, it is safe to say that engaging in leisure activities leads to improving the quality of life (Brajša-Žganec, Merkaš, \& Šverko, 2011).

Offering recreational facilities are an exemplary way of engaging different people from the community in order to participate and socialize with one another. Similarly, it is a great opportunity for the people of determination in order to participate and engage with the community (Lord \& Stein, 2009). Furthermore, obtaining recreation centers are extremely popular nowadays. For example, the demand of requiring a student recreation center in universities has increased in the United States of America. It is worth mentioning that obtaining a suitable student recreation center can act as a catalyst in pursuing certain students to a university. As a result, several universities in the United States of America have upgraded their recreation centers in order to attract as much students as possible. For instance, these developments include offering an Olympic sized swimming pool, leisure pool, indoor jogging trail, gymnasium, squash court, boxing ring, cardio fitness area, weightlifting space, indoor rock climbing wall, as well as offering various shower rooms and free equipment (Omar-Fauzee, Yusof, \& Zizzi, 2009). Moreover, the participation in sports recreational activities can help young people who migrate to a different country in settling in and feeling socially included. Likewise, recreational sports activities are a fun and healthy process that can further develop their language skills and other aspects as well (Doherty \& Taylor, 2007). Fifthly, policies in sport have grown immensely and evolved in many countries all over the world. Besides, rules, regulations and policies are currently considered as the foundation that protects the sports sector from many undesirable aspects that could harm the institution. It is worth mentioning that acquiring policies is integral in order to have sport development in any country (Shilbury, Sotiriadou, \& Green, 2008).

Nowadays governance and policies in sports obtain huge importance in the sector, and is a strictly essential characteristic to be present in order to carry out different sporting activities in an honest, ethical, fair, and moral way (Ferkins, Shilbury, \& McDonald, 2005). Similarly, sport governance is not only identified as a beneficial tool to be utilized in order to analyze and study different policies, but also it can act as a policy maker as well as a policy implementer in the world of sports (Grix, 2010). Sixthly, facilities management is a term mainly involved with effectiveness management of already built assets. Managing facilities is a process that requires various multisectoral actions, and obtains massive information needs. Moreover, there are many software that operate in a way to help directors in managing their facilities, as these software acquire may benefits for the users such as various visualizations, in depth analysis, advanced overall control of the facility and much more. Similarly, by using a facilities management software, potential issues regarding maintenance can be easily detected as well controlling costs is significantly simpler (Becerik-Gerber et al, 2012; Amaratunga, Baldry, \& Sarshar, 2000).

It is worth mentioning that facilities management began to gradually flourish mainly in the past two decades. This was due to the widespread influence that information technology had begun to have on the world as a whole. For instance, in Japan, facilities management is considered as a vital aspect that leads a country towards economic success. Furthermore, this process is believed to be a method of improving and developing overall effectiveness (Alexander, 2003).

\section{Methodology}

This study depended on both qualitative as well as quantitative methods in research. Qualitative methods included scheduled visits to the 5 grand parks in order to observe various aspects in the parks. Quantitative methods included gathering several geoprocessing information for the purpose 
of the study. The software used for the geoprocessing in this research is ArcMap version 10.7.1. The recommendation for the usage of the ArcMap came from Blake (2019) and Latta et al (2013). Regarding statistics and analysis, the database used was the Population Bulletin Emirate of Dubai 2018 (Dubai Statistics Center, 2018). The Base-map applied adopted $30 \mathrm{~cm}$ image resolution as scale for each source. The purpose behind opting for the usage of a Base-map includes providing necessary information in order to analyze the location (Xing \& Brimblecombe, 2020; Elmes et al, 2020; Tusznio et al, 2020; Cârlan et al, 2020; Bennett et al, 2020). In order to use the best information from different Base-map Gallery for plotting and analyzing data across large geographic areas of Dubai, this research monitored and collected enlightenments from the following sources Esri, DigitalGlobe, GeoEye, Earthstar Geographics, CNES/Airbus DS, USDA, USGS, AeroGRID, IGN, and the GIS User Community. The respective map analysis occurred from the $1^{\text {st }}$ of March till the $15^{\text {th }}$ of April 2020. This study used Geospatial Information to analyze the parks area in Dubai. Furthermore, trips were scheduled to visit the parks in order to observe different elements and features in the parks. Observations included the following: the parks' working hours, entry fees, discounts offered, availability of loyalty programs, rules and policies in the parks before and after Covid-19, level of accessibility especially for people of determination, facilities and services offered, degree of presence in social media websites, types of children playground equipment offered as well as their quality, availability of prayer rooms, toilets, and benches in all the parks, and finally degree of safety and security in the parks. The aim of this investigation is to analyze several forms of geoprocessing information regarding Dubai's grand parks as well as exploring existing offerings, Covid-19 restrictions undertaken by the parks, and propose solutions for parks administrations for innovative offerings.

\section{Data analysis}

Below map incudes the United Arab Emirates in blue, and the emirate of Dubai is indicated in red. The 5 selected parks for this study are all located in the emirate of Dubai. The total population of the UAE is comprised of 9,876,940 individuals (Worldometer, 2020). Furthermore, there are $3,355,900$ individuals living in the Emirate of Dubai. Moreover, the total number of Emiratis in Dubai are assessed to be 263,450 individuals, and the Non-Emiratis are estimated to be 3,092,450 individuals (Dubai Statistics Center, 2019a, 2019b).

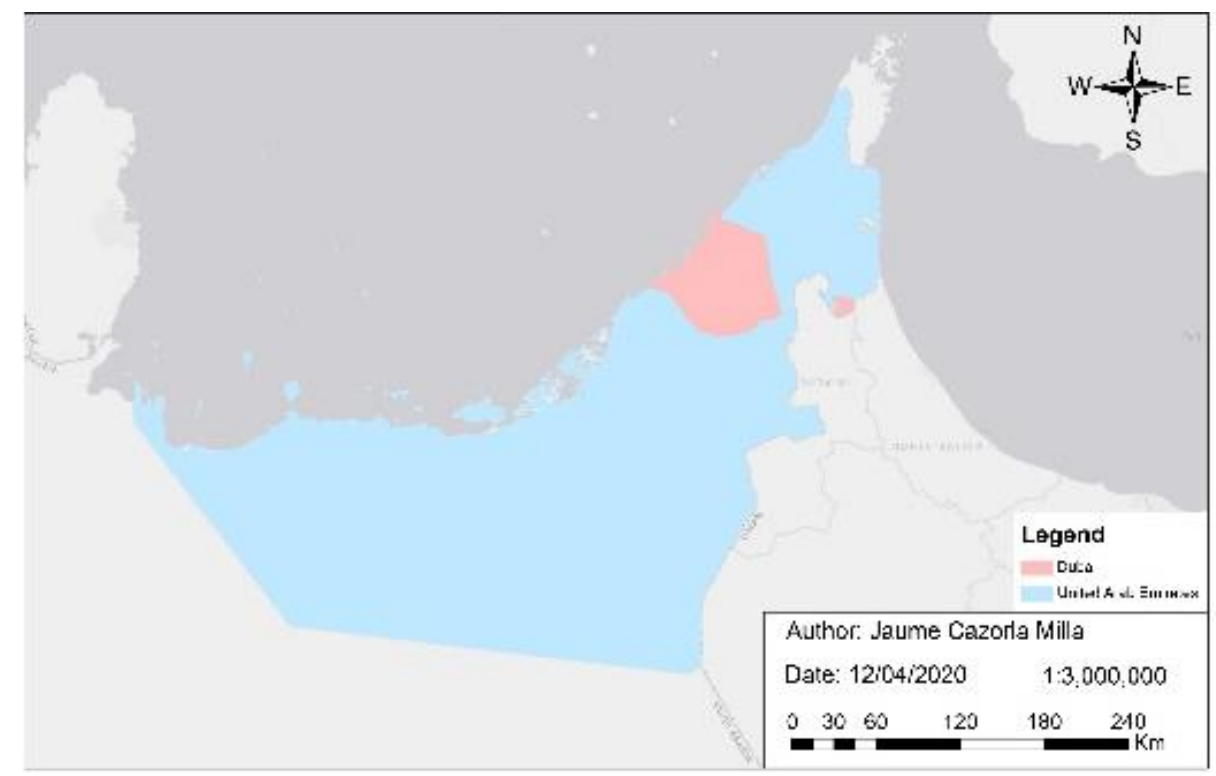

Figure 1. Map of the United Arab Emirates in KM Scale. Source: Population Bulletin Emirate of Dubai 2018 (Dubai Statistics Center, 2018).

\subsection{Location of the Parks}


Public parks as well as private parks are important spaces that should exist in any neighborhood in any country. That is due to the fact that parks play an important role in providing sufficient places for people to visit and engage in different activities as well as adding more value to the neighborhood containing the park (Walker, 2004).Parks are ideal destinations for purposes such as sport, leisure, and recreation to help individuals that are seeking a healthy lifestyle (Cohen et al, 2007). However, rules and policies are of high importance in order to maintain and manage these facilities offered to the community.

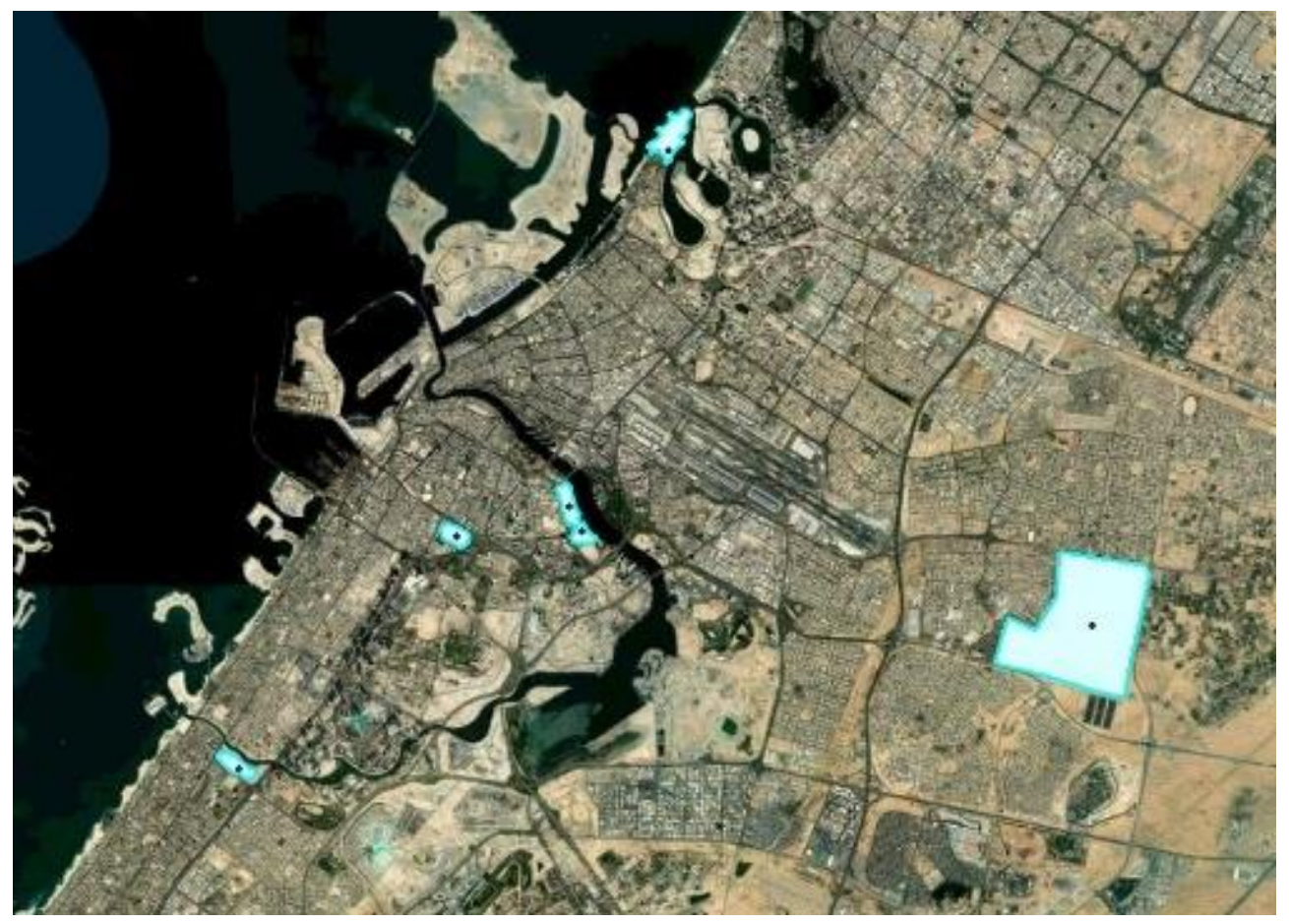

Figure 2. Map of the 5 Grand Parks in Dubai. Source: Population Bulletin Emirate of Dubai 2018 (Dubai Statistics Center, 2018).

Offering parks close to people and including them in neighborhoods as necessary landmarks can lead to obtaining the triple bottom line benefits (economic, social, and environmental) as well. As a result, benefits will include all segments of society which include offering options for both genders, families, young children, adults, elderly seniors, and the people of determination.

\subsection{Transportation to the Parks}

Transportation to parks is one of the key aspects that can motivate people to visit parks. For instance, when transportation is mobile and easily undertaken, then a person would be motivated to visit parks frequently and repeatedly. When transportation is not easily available, takes a lot of time and distance, or is relatively expensive, then an individual might opt to not visit a park and use any other services provided. Therefore, since Dubai does not provide a park in every area in the Emirate, it is a key feature that adequate, flexible, and cheap methods of transportation are provided from every single neighborhood to the grand parks or any park, in order to benefit more park visitors as well as satisfy the society's needs. 


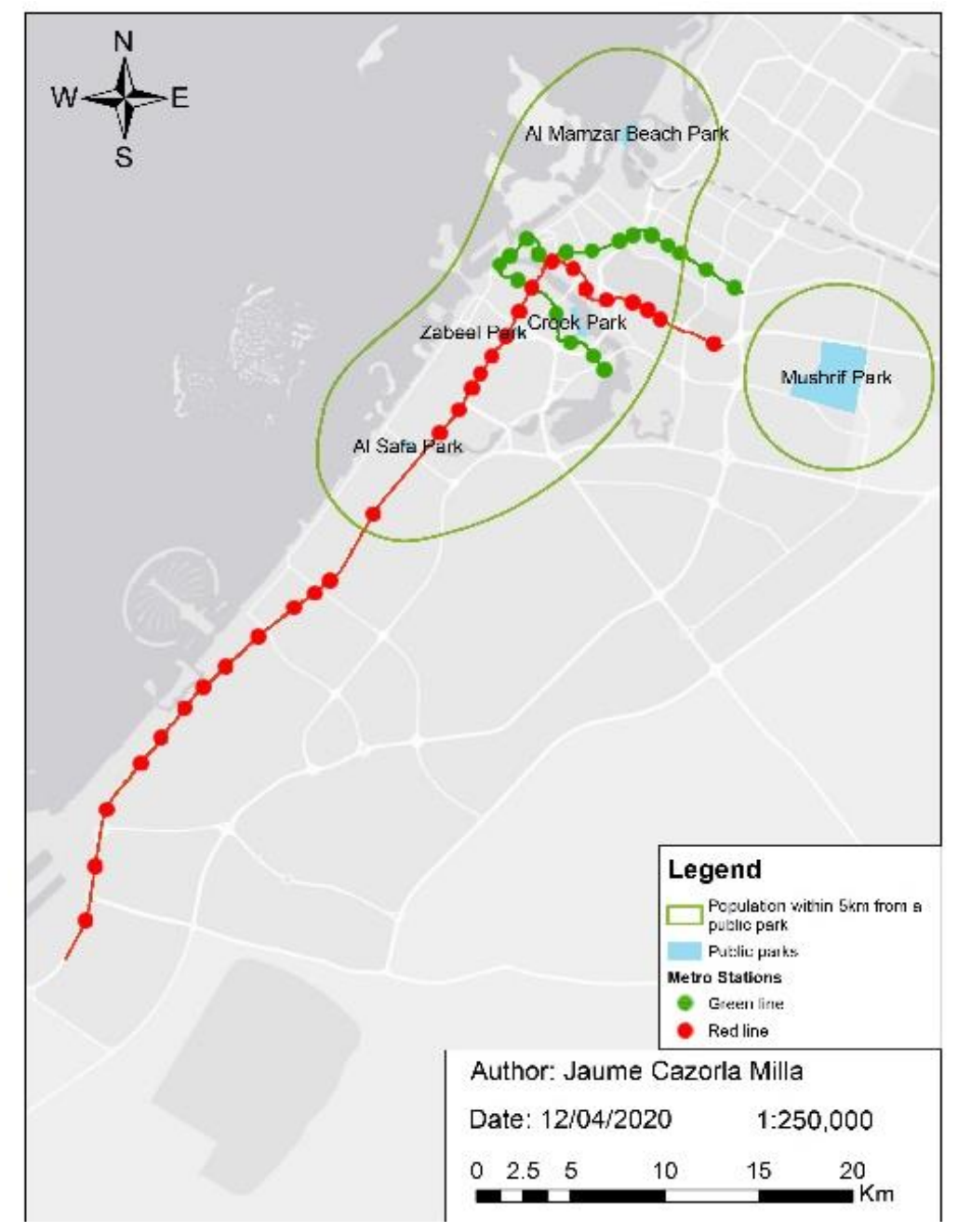

Figure 3. Metro Stations Near the Location of the Grand Parks. Source: Population Bulletin Emirate of Dubai 2018 (Dubai Statistics Center, 2018).

The 5 grand parks that are being analyzed are included in the above map. The Dubai metro stations that are closest to the parks are also provided in the red and green lines. However, a key thing to remember is that the metro stations are not really close to some the parks. Additionally, population within 5 kilometers from the parks have been identified by the green outlining as per the latest data bank provided for geoprocessing which was in 2018.

Table 2. Metro Stations Near the Grand Parks.

\begin{tabular}{|c|c|c|c|c|c|c|c|c|c|}
\hline & Grand Parks & $\begin{array}{l}\text { Perim } \\
\text { eter } \mathrm{m}\end{array}$ & Area $m^{\wedge} 2$ & $\begin{array}{c}\text { Nearest } \\
\text { metro }\end{array}$ & & 2nd Nearest metro & & $\begin{array}{c}\text { Pop } 1 \\
\text { km }\end{array}$ & $\begin{array}{c}\text { Pop } 5 \\
\text { km }\end{array}$ \\
\hline 1 & Al Safa Park & 2,788 & 348,249 & $\begin{array}{c}\text { Business } \\
\text { Bay }\end{array}$ & $1.8 \mathrm{~km}$ & Noor Bank & $4 \mathrm{~km}$ & 78,465 & 516,803 \\
\hline 2 & $\begin{array}{c}\text { Al Mamzar } \\
\text { Beach } \\
\text { Park } \\
\end{array}$ & 4,955 & 779,637 & $\begin{array}{c}\text { Al } \\
\text { Qiyadah }\end{array}$ & $5 \mathrm{~km}$ & Stadium & $\begin{array}{l}5.2 \\
\mathrm{~km}\end{array}$ & 14,180 & 319,754 \\
\hline 3 & Mushrif Park & 13,859 & $9,718,377$ & $\begin{array}{c}\text { Rashidiy } \\
\text { a }\end{array}$ & $6.8 \mathrm{~km}$ & Etisalat & $\begin{array}{l}7.3 \\
\mathrm{~km}\end{array}$ & 63 & 147,217 \\
\hline 4 & Zabeel Park & 2,216 & 333,013 & $\begin{array}{c}\mathrm{Al} \\
\text { Jafiliya } \\
\end{array}$ & $0.7 \mathrm{~km}$ & $\mathrm{ADCB}$ & $\begin{array}{l}1.2 \\
\mathrm{~km}\end{array}$ & 146,595 & 795,341 \\
\hline 5 & Creek Park & 4,878 & 631,809 & $\begin{array}{c}\text { Oud } \\
\text { Metha }\end{array}$ & $1.1 \mathrm{~km}$ & Dubai Healthcare City & $\begin{array}{l}1.3 \\
\mathrm{~km}\end{array}$ & 31,749 & 850,696 \\
\hline
\end{tabular}

Source: Population Bulletin Emirate of Dubai 2018 (Dubai Statistics Center, 2018). 
It is worth mentioning that the distance from the grand parks and the metro stations are not very close, and park visitors that are using the metro for reaching the parks might use other modes of transportation to reach the entrance of the parks after getting off the metro, such as taxis, Uber, RTA busses, walking, or any other modes. Moreover, the distance of the closest metro station to Mushrif Park $(6.8 \mathrm{~km})$ as well as Al Mamzar Beach Park $(5 \mathrm{~km})$ should be pointed out as the distance is certainly far away from these two parks, and a different type of transportation is definitely necessary to be taken to reach the park which could not suit some park visitors. Besides, when children or young adults are planning for a park visit, a crucial factor for the parents is that safety should be ensured all the way to the park and from the park. Therefore, sufficient transportation methods and techniques should be provided not only to make sure that the children are able to get to the parks as well as come back home in a secure and protected manner, but also to attract more people and visitors to the parks as mobile and flexible transportation can affect the decision of whether to visit a park or not.

\subsection{Population Surrounding the Grand Parks}

The below Figure 4 includes the 5 grand parks as well as the closest metro stations to the parks. Furthermore, the map also includes the number of population in all the areas surrounding the 5 parks as well as the number of people living in other areas in Dubai according to the latest data bank available for geoprocessing which was in 2018.

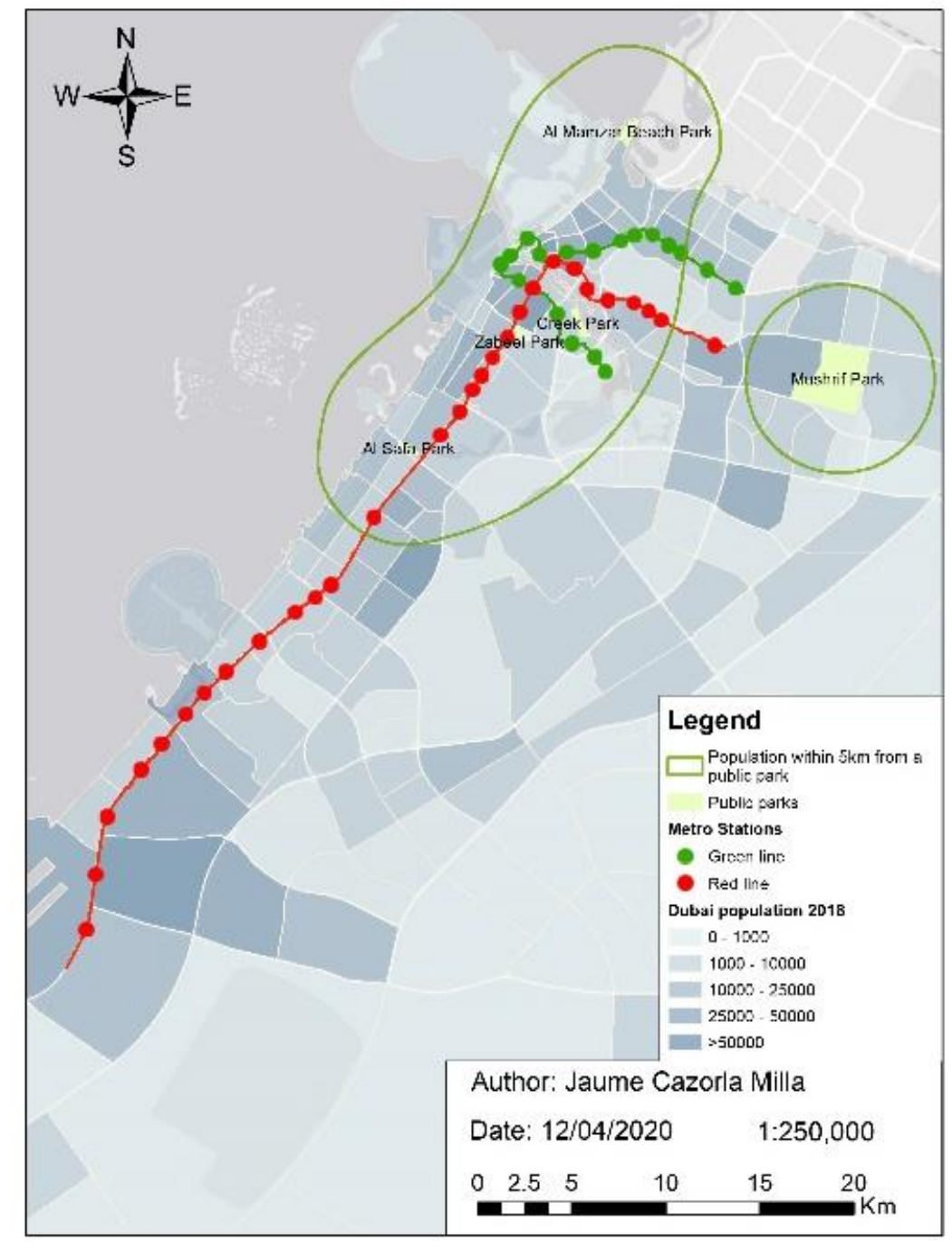

Figure 4. Population Surrounding the Grand Parks. Source: Population Bulletin Emirate of Dubai 2018 (Dubai Statistics Center, 2018). 
It is worth mentioning, that the addition of parks to areas in which there is a significant amount of population is always an efficient and well-planned decision. Moreover, it is crucial that accessibilities are added to the population surrounding the parks, in order to have frequent park visitors that will always stay satisfied with the park offerings. However, as previously mentioned, not all areas in Dubai include having a park in the neighborhood or community. Therefore, a vital recommendation includes adding private or public parks in every single area or neighborhood in Dubai. In other words, parks should be considered as necessary and important aspects to add in every community and counted similar to supermarkets or pharmacies, in order to gain the many benefits that this project obtains for both the country as well as the society. Moreover, adding parks to every community in Dubai would ensure numerous benefits to the country which include economic, social, and environmental advantages as well (Batra, 2014; Gies, 2009; Sherer, 2006).

Economic benefits include attracting tourists to the park and showcasing not only the park, but also the community that is surrounding the park, also the image of the park can present the park as an adequate destination for hosting multiple events. Furthermore, using the parks innovative and creative unique offerings as marketing tools could also benefit the country as a whole. For example, the UAE could showcase the illuminated garden in Zabeel Park or the Mystical Mirror Maze in Creek Park as unique and rare offerings. Social benefits can include having more families moving to live in these areas as offerings of the community would include a park which would ensure many advantages to families, such as having a close by and safe place that young people can visit and engage in multiple activities which would benefit children greatly as it would be a place they could meet friends and engage in sporting activities, but in places that are made for performing sports. Families would also benefit from the availability of having adequate places in which the group could gather all together in one place for different activities. For instance, going for picnics or barbeques in the parks. Moreover, as many people from the community would be visiting the park for the purpose of performing sporting activities, this will lead to encouraging more people to perform sport in the UAE and will contribute to improving not only physical, but also wellbeing, through mental health of park users as the park would be close to their access and they will visit the park frequently. Furthermore, the park could act as a factor in strengthening community relationship, as the community would have a suitable place in which they can meet, connect, share interests, and become close friends. Environmental benefits include providing more green spaces in the neighborhood which contributes to making Dubai a greener place. Moreover, the parks could contribute to nurturing a suitable habitat for some animals and plants as seen in Mushrif Park they presented a sign that prohibits animal hunting. Similarly, a lot of squirrels and birds were present in Al Safa Park. Lastly, increasing the number of trees in several areas will contribute to reducing air and water pollution as well as providing higher levels of Oxygen. The process of adding a park in every single community would reestablish the reputation of Dubai in terms of being a socially responsible country that continuously finds new ways to satisfy their residents in every way possible, as the most best reputation and the highest praise should always be provided for a blessed country like the UAE.

Table 3. Communities around $1 \mathrm{~km}$ and $5 \mathrm{~km}$ radius from Grand Parks. 

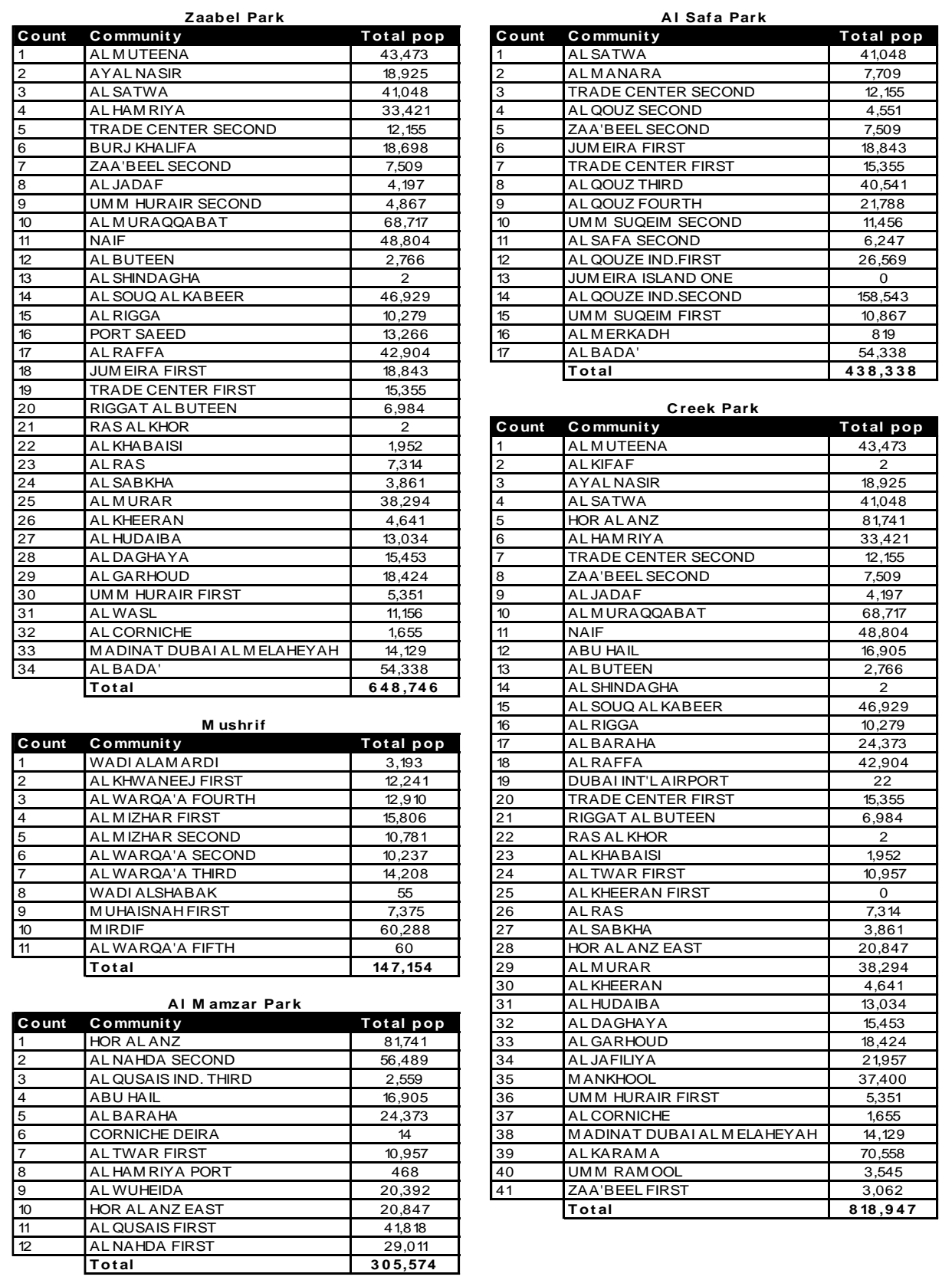

\begin{tabular}{|c|c|c|}
\hline 1 & AL MUTEENA & 43,473 \\
\hline 2 & AL KIFAF & 2 \\
\hline 3 & AYAL NASIR & 18,925 \\
\hline 4 & ALSATWA & 41,048 \\
\hline 5 & HOR AL ANZ & 81,741 \\
\hline 6 & AL HAM RIYA & 33,421 \\
\hline 7 & TRADE CENTER SECOND & 12,155 \\
\hline 8 & ZAA'BEEL SECOND & 7,509 \\
\hline 9 & AL JADAF & 4,197 \\
\hline 10 & AL MURAQQABAT & 68,717 \\
\hline 11 & NAIF & 48,804 \\
\hline 12 & ABU HAIL & 16,905 \\
\hline 13 & ALBUTEEN & 2,766 \\
\hline 14 & AL SHINDAGHA & 2 \\
\hline 15 & AL SOUQ AL KABEER & 46,929 \\
\hline 16 & AL RIGGA & 10,279 \\
\hline 17 & ALBARAHA & 24,373 \\
\hline 18 & ALRAFFA & 42,904 \\
\hline 19 & DUBAI INT'L AIRPORT & 22 \\
\hline 20 & TRADE CENTER FIRST & 15,355 \\
\hline 21 & RIGGAT AL BUTEEN & 6,984 \\
\hline 22 & RAS AL KHOR & 2 \\
\hline 23 & AL KHABAISI & 1,952 \\
\hline 24 & AL TWAR FIRST & 10,957 \\
\hline 25 & AL KHEERAN FIRST & 0 \\
\hline 26 & ALRAS & 7,314 \\
\hline 27 & AL SABKHA & 3,861 \\
\hline 28 & $\begin{array}{l}\text { HOR AL ANZ EAST } \\
\end{array}$ & 20,847 \\
\hline 29 & ALMURAR & 38,294 \\
\hline 30 & AL KHEERAN & 4,641 \\
\hline 31 & AL HUDAIBA & 13,034 \\
\hline 32 & ALDAGHAYA & 15,453 \\
\hline 33 & AL GARHOUD & 18,424 \\
\hline 34 & AL JAFILIYA & 21,957 \\
\hline 35 & MANKHOOL & 37,400 \\
\hline 36 & UMM HURAIR FIRST & 5,351 \\
\hline 37 & AL CORNICHE & 1,655 \\
\hline 38 & MADINAT DUBAI AL M ELAHEYAH & 14,129 \\
\hline 39 & AL KARAMA & 70,558 \\
\hline 40 & UMM RAM OOL & 3,545 \\
\hline \multirow[t]{2}{*}{41} & ZAA'BEEL FIRST & 3,062 \\
\hline & Total & 818,947 \\
\hline
\end{tabular}

Source: Population Bulletin Emirate of Dubai 2018 (Dubai Statistics Center, 2018).

It was observed the communities living close radius from Grand Parks, as seen in Table 3. The data summarizes the ID database, community number, area, and perimeter of the communities. Moreover, the number of residents in each one of these communities is provided as well as the total number of residents $1 \mathrm{~km}$ away from Al Safa Park which is 78,465 individuals in 2018. The table also represents communities around $1 \mathrm{~km}$ from Al Mamzar Beach Park as well as their ID database, community number, area, and perimeter of the communities. Moreover, the number of residents in each one of these communities is provided as well as the total number of residents $1 \mathrm{~km}$ away from Al Mamzar Beach Park which is 14,180 individuals in 2018. The communities around $1 \mathrm{~km}$ from Mushrif Park as well as their ID database, community number, area, and perimeter of the communities. Moreover, the number of residents in each one of these communities is provided as well as the total number of residents $1 \mathrm{~km}$ away from Mushrif Park which is 63 individuals in 2018. The communities around $1 \mathrm{~km}$ from Zabeel Park as well as their ID database, community number, area, and perimeter of the communities. Moreover, the number of residents in each one of these 
communities is provided as well as the total number of residents $1 \mathrm{~km}$ away from Zabeel Park which is 146,595 individuals in 2018. The communities around $1 \mathrm{~km}$ from Creek Park as well as their ID database, community number, area, and perimeter of the communities. Moreover, the number of residents in each one of these communities is provided as well as the total number of residents $1 \mathrm{~km}$ away from Creek Park which is 31,749 individuals in 2018.

Table 4. Total Number of People Living $1 \mathrm{~km}$ and $5 \mathrm{~km}$ from the Grand Parks.

\begin{tabular}{cccc}
\hline Count & Grand Parks & $\begin{array}{c}\text { Number of People Living } \\
\mathbf{1 k m} \text { from the Grand Parks }\end{array}$ & $\begin{array}{c}\text { Number of People Living } \\
\text { 5km from the Grand Parks }\end{array}$ \\
\hline 1 & Al Safa Park & 78,465 & 438,338 \\
\hline 2 & Al Mamzar Beach Park & 14,180 & 305,574 \\
\hline 3 & Mushrif Park & 63 & 147,154 \\
\hline 4 & Zabeel Park & 146,595 & 648,746 \\
\hline 5 & Creek Park & 31,749 & 818,947 \\
\hline & TOTAL Residents & $\mathbf{2 7 1 , 0 5 2}$ & $\mathbf{1 6 7 4 4 7 6}$ \\
\hline
\end{tabular}

Source: Population Bulletin Emirate of Dubai 2018 (Dubai Statistics Center, 2018).

As mentioned earlier, the population of Dubai is 3,192,275 individuals, and the total number of residents $1 \mathrm{~km}$ away from a grand park is 257,436 individuals. Therefore, in order to calculate the percentage of residents staying $1 \mathrm{~km}$ away from a grand park the following equation is performed:

(Total number of residents $1 \mathrm{~km}$ away from a grand park / Total number of Dubai residents) $\mathrm{x}$ $100=(257,436 / 3,192,275) \times 100=8 \%$.

Hence, $8 \%$ of Dubai's residents stay $1 \mathrm{~km}$ away from a grand park.

The population of Dubai is 3192275 individuals, and the total number of residents $5 \mathrm{~km}$ away from a grand park is 1674476 individuals. Therefore, in order to calculate the percentage of residents staying $5 \mathrm{~km}$ away from a grand park the following equation is performed:

(Total number of residents $5 \mathrm{~km}$ away from a grand park / Total number of Dubai residents) $\mathrm{x}$ $100=(1674476 / 3192275) \times 100=52 \%$

Hence $52 \%$ of Dubai's residents stay $5 \mathrm{~km}$ away from a grand park.

\subsection{Grand parks visitors}

The number of people in the society "including all categories" that visited each one of the five grand parks concerning the years 2017, 2018, and 2019 is observed in Table 5. Moreover, the table provides the total number of people in the society who visited the grand parks each year since 2017 till 2019. As indicated by the table, the total number of grand park visitors in 2019 has decreased since 2017. Not to mention that the total number of grand park visitors in 2020 will be even less due to the Covid-19 lockdown rules and the closing down of the parks for a large period of time. Moreover, individually speaking, in 2019 almost all of the grand parks have experienced their lowest number of park visitors since 2017, which is a negative statistic that needs improvements and developments.

Table 5. Number of Park Visitors in the Last 3 Years.

\begin{tabular}{ccccc}
\hline Count & Grand Parks & 2017 Visitors & 2018 Visitors & 2019 Visitors \\
\hline 1 & Al Safa Park & 218,131 & 212,712 & 208,785 \\
\hline 2 & Al Mamzar Beach Park & $1,900,971$ & $1,744,203$ & $1,584,632$ \\
\hline 3 & Mushrif Park & $1,152,808$ & $1,127,069$ & $1,055,231$ \\
\hline 4 & Zabeel Park & 801,572 & 590,142 & 725,263 \\
\hline 5 & Creek Park & $\mathbf{1 , 1 7 4 , 6 7 1}$ & $\mathbf{1 , 3 0 6 , 5 9 2}$ & $\mathbf{1 , 0 6 7 , 1 5 3}$ \\
\hline & TOTAL Visitors & $\mathbf{5 , 2 4 8 , 1 5 3}$ & $\mathbf{4 , 9 8 0 , 7 1 8}$ & $\mathbf{4 , 6 4 1 , 0 6 4}$ \\
\hline & Most visitors & Average visito & \multicolumn{2}{c}{ Least visitors }
\end{tabular}


Lack of innovation could certainly be one of the reasons in which park visitors have decreased. As mentioned earlier, innovation and creativity in park offerings is vital in order to keep on growing and sustaining growth without falling back. Therefore, all of the grand parks must use their imagination, strategize and establish well-planned long-term park offerings in which they are required to include innovation, creativity, and the trending desires of the society. For instance, including more innovative offerings such as the illuminated garden in Zabeel Park or the Smart services included in Al Mamzar Beach Park. In order to keep on attracting many park visitors from all the different segments in the UAE society which include families, children, both genders, elderly people and the people of determination. Besides, to make sure that they are satisfied with the offerings and that they would keep on returning to the parks. The number of people who visited grand parks concerning the years 2017, 2018, and 2019 are summarized in Figure 5.

\section{Grand Parks Visitors}

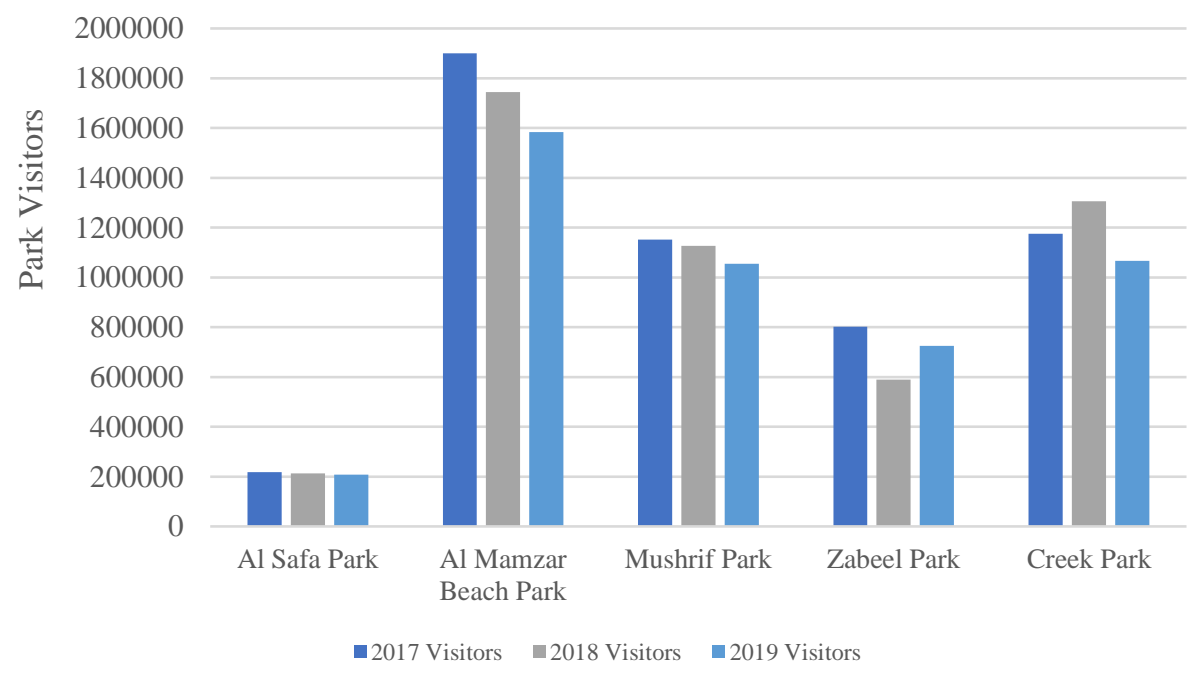

Figure 5. Grand Parks Visitors. Source: Adopted from Dubai Municipality (2020b).

\section{Conclusion and future recommendations}

In conclusion, the UAE is clearly exerting enormous efforts in order to provide not only the tourists, but also the residents with several forms of entertainment and leisure that is beneficial as well as educational for all ages. However, it is worth mentioning that the process of improving and providing better offerings should always be present. Dubai is a city known all over the world for being an emirate that always craves undergoing improvements, developments, and enhancements to the region in order to reach world renown global stages. Similarly, Dubai always strives to establish innovative projects and visions in order to reach these global stages. Therefore, it would be a wise decision to establish a long-term vision for Dubai in order to get $100 \%$ of the residents in the emirate to be just $5 \mathrm{~km}$ away from a grand park. Moreover, this strategy should also aim to increase the number of residents staying $1 \mathrm{~km}$ away from a grand park in order to achieve two goals with one vision, and to raise the percentage of the people living $1 \mathrm{~km}$ away from a grand park. For instance, building a new grand park in the emirate would be good project to incorporate all residents to be $5 \mathrm{~km}$ away from a grand park. However, a new grand park must be built in a strategic location that withholds a large number of residents that are staying far from the 5 existing parks. Moreover, this type of project would encourage in developing the reputation of Dubai, so that it can be considered an emirate that constantly searches for new ideas and projects to further satisfy all the segments in their society and include them, as well as help them in terms of maintaining a healthy lifestyle. Nonetheless, if Dubai does decide to build a new grand park, the park should not be similar to any other park in the entire GCC region. Similarly, planning and setting strategies should include a lot of time for such a project as it would hold immense advantages for the country if properly done, and it 
should be considered as a long-term project. The park should be as unique as possible and include the latest innovative ideas that could be implemented in parks as well as offerings that satisfy all the segments existing in the emirate. Furthermore, this type of project is highly required to be one of a kind in order to benefit from all the triple bottom line effects. Benefits of building such a park should include economic gains that improve the UAE's economy. The social benefits should be existing as the emirate should constantly provide the community with these types of projects as well as accessibilities. Finally, environmental benefits must be present with this project as building this park would include more trees, green spaces, and higher levels of sustainability in the country.

It is worth mentioning that if the Government of Dubai goes further in implementing this project, the park should be designed to be an Olympic Park, which would aid the possibility of Dubai hosting the Summer Olympic Games in the future or even the Winter Olympic Games as they would acquire a state of the art Olympic Park. Besides, as mentioned earlier the latest technologies should be incorporated with the new park, so the inclusion of artificial snow would be a judicious idea in boosting the image of Dubai in terms of hosting the Winter Olympic Games. Moreover, it is a wellknown fact that many world renown athletes welcome the idea of travelling to visit Dubai for multiple purposes. Therefore, this Olympic Park should contain the greatest and latest sports offerings regarding all sports, in order to attract many athletes to come visit Dubai and use these facilities for training, so that they would boost the image of Dubai. Furthermore, the following recommendations are selected for the purpose of not only maintaining current status of the country's offerings, but also in order to develop and enhance the park visitors' experience when visiting the parks. Firstly, there are multiple new innovative ideas in which park managers and developers are choosing to follow in their parks. For example, the water feature or the floor fountain that is located in the Queen Elizabeth Olympic Park, Stratford, London is an ideal new idea that could be implemented in the UAE, it would offer kids a new way of having fun and playing with water as well as it is considered safer than going to a swimming pool (Davis Landscape Architecture, 2014). A key aspect in designing grand or public parks should include the culture of the country inside them. For example, including drawings or pictures inside the parks such as palm trees, old ships, cactuses, desert sand, and much more. As a result, the park would be presenting and showcasing the culture of the UAE in the design of the parks which is a key aspect that could benefit the UAE in general. Additionally, tourists that visit the UAE for the first time and then organize a trip to go to the parks could also learn and get educated about the history of the UAE and what are the key symbols that represent the culture of the country through these drawings (Karim Elsayyad, 2019). Thirdly, as it is well noticed around the world, eSports became immensely popular and extremely favored by a vast number of people. Moreover, this popularity has led to the organizing of many international eSports competitions in which huge prizes ae rewarded for the winner. Whether eSports is considered as a sport or not is a different subject, but there is no denying that countless people all over the world are choosing to be part of it at the moment (Llorens, 2017).

Specific areas which provide park visitors the opportunity to engage in eSports should be adapted in Dubai's grand parks. Regardless of considering them as sports or not, eSports are hugely popular and several segments in society favor them and are well receptive to playing them. Especially that in a country like the UAE a lot of young adults that are friends set up gatherings in which they organize a small friendly tournament between them while playing eSports as a leisure activity. Moreover, eSports tournaments could be organized in the facilities offered at the grand parks with prizes for the winners to attract more visitors.

A new creative and innovative method of doing sports nowadays include the usage of augmented reality. Augmented reality offers the user with the opportunity of adding different aspects and features to the already existing reality in front of the person (Emspak, 2018). Moreover, it comes in different forms and types in many divisions such as in gaming, helping engineers to decide the best option to pursue for the project, aiding interior designers in figuring out which colors and styles mix and match together for houses, as well as being used in many other departments such as education, manufacturing, healthcare and retail. Besides, one of the most well-known examples the involves the usage of augmented reality in the sports world includes the Hawkeye technology to spot in an extremely accurate manner whether in football if the ball has crossed the goal line, or in 
tennis if the ball has landed on the opponent's line (Joshi, 2019). Moreover, IKEA is a company that previously released an augmented reality application which enables users to pick from over 2,000 IKEA products in order to view how they match in their homes with incredibly accurate results provided. For example, once a product is chosen, the user drags the furniture to the favored location at home using the camera and drops it to see how it appears, and recently they included the multi placement feature which enables the user to showcase more than one product at the same time (Mogg, 2019; Liszewski, 2019; Ayoubi, 2017; Joseph, 2017). Additionally, it is expected that augmented reality in the future would not be directly linked to only phones and tablets, but also to glasses as Google is one of the companies that are working on such a project, and several glasses are already existing (Emspak, 2018).

During the visits to the grand parks, locating the facilities was challenging. Searching for the signs that lead to the facility, or the overall park map was tiring and slightly draining. Therefore, as previously mentioned, it is highly important to incorporate technology with the facilities available in the parks as well as making it easily accessible for all people. As a result, park visitors should be able to use augmented reality via applications provided from the park to find out information about specific services or playground facilities in the park. For instance, park visitors would use their phone in order to know a specific slide is preferable for what age group for kids and if it is not recommended for a specific age group, finding out which muscle group is worked out when certain activities are performed, providing explanatory videos on the safest and correct way in which the facility is used, and so much more features. They would simply point the phone towards a specific facility and multiple windows would pop up in their phone explaining several aspects regarding the service. Another example could include offering augmented treasure hunts in the parks that include people searching for different augmented objects. As the hunters will be walking and occasionally running during the hunt they will be practicing physical activity indirectly at the same time. Moreover, this could also act as way to ensure children are maintaining social distancing. When searching for the objects children will be using the augmented reality on their phones, and will have an "imaginary shield" that would cause the phone to ring and vibrate when coming near other hunters as well as it will be deducting points from them as long as they are near the other hunters. In order to keep a high score and not lose points, they will have to move far away from the other hunters. Hence, social distancing will be ensured from them and they will be rewarded from the parks when completing the treasure hunt (Mataruna \& Ahmed, 2020).

The park visitors could use this feature to view reviews and comments provided by previous users of these facilities in order to find the best facilities to use and what to avoid, also this would allow park organizers to analyze the comments of the public and improve the facilities that the people are not satisfied with. In addition, this can provide people with a sense of communication and a social engine to connect with each other. Furthermore, the usage of augmented reality can not only help people with the sporting and leisure facilities, but also in helping people to find several park services with providing different information about where the person wants to reach such as providing directions to the facility, the distance to reach, estimated time to reach, and other relevant data.

The augmented reality could help people in order to reach facilities such as: the nearest bathroom, directions to the prayer room, what facilities and services are present in the park and providing directions to reach them, and it can aid people in identifying which recycle bin is the appropriate bin for throwing in it specific wastes which contributes to being not only socially responsible, but also environmentally responsible. Based on the World Health Organization and the government of Dubai, the following guidelines are required to be provided in all parks due to the Covid-19 outbreak: (WHO, 2020a, 2020b; Government of Dubai, 2020). Finally, as mentioned earlier Dubai is a city that always strives to improve and develop from all angles in order to reach the best global status. It is worth mentioning that Dubai is considered as a city that is fully able to include all the recommendations provided in this study, and even more new innovative offerings to their grand parks. Moreover, adapting to new rules and policies in relation to the Covid-19 could take some time in Dubai, but it will surely be planned for strategically by the government in order to return with a safer "new normal" lifestyle for residents as well as tourists. However, the real challenge that Dubai faces after the opening of the grand parks and other facilities post Covid-19 is to ensure that all people 
are complying to the rules and are taking necessary safety precautions. Therefore, educating people and spreading awareness is key to ensure that Dubai's society is well informed about the severity of the situation as well as to deliver the message of which "we are all in this together".

\section{References}

1. Alexander: K. (2003). A strategy for facilities management. Facilities, 21(11-12), 269-274. DOI: http://dx.doi.org/10.1108/02632770310500338 (Accessed 2/5/2020)

2. Amaratunga, D., Baldry, D., \& Sarshar, M. (2000). Assessment of facilities management performance - what next? Facilities, 18 (1/2), 66 - 75. DOI: http://dx.doi.org/10.1108/02632770010312187 (Accessed 2/5/2020)

3. Ammar, A., Chtourou, H., Boukhris, O., Trabelsi, K., Masmoudi, L., Brach, M., ... \& Mueller, P. (2020). Covid-19 home confinement negatively impacts social participation and life satisfaction: A worldwide multicenter study. International Journal of Environmental Research and Public Health, 17(17), 6237. https://doi.org/10.3390/ijerph17176237 (Accessed 1/10/2020)

4. Ayoubi, A. (2017). IKEA Launches Augmented Reality Application. Available at: https://www.architectmagazine.com/technology/ikea-launches-augmented-reality-application o (Accessed 7/7/2020)

5. Banerjee, T. (2001). The Future of Public Space: Beyond Invented Streets and Reinvented Places. Journal of the American Planning Association, 67(1), 9-24. DOI: https://doi.org/10.1080/01944360108976352 (Accessed 19/3/2020)

6. Batra, A. (2014). Community Benefits of Green Areas $\mathcal{E}$ Parks. Available at: https://www.linkedin.com/pulse/20140922075014-150737338-architecture-and-urban-planning/ (Accessed $7 / 6 / 2020)$

7. Becerik-Gerber, B., Jazizadeh, F., Li, N., \& Calis, G. (2012). Application areas and data requirements for BIM-enabled facilities management. Journal of construction engineering and management, 138(3), 431-442. DOI: http://dx.doi.org/10.1061/(ASCE)CO.1943-7862.0000433 (Accessed 2/5/2020)

8. Bedimo-Rung, A., Mowen, A., \& Cohen, D. (2005). The significance of parks to physical activity and public health. American Journal of Preventive Medicine, 28(2), 159-168. DOI: https://doi.org/10.1016/j.amepre.2004.10.024 (Accessed 4/1/2020)

9. Bennett, C., Della Giustina, D., Becker, K., Becker, T., Edmundson, K., Golish, D., Bennett, R., Burke, K., Cue, C., Clark, B., Contreras, J., Deshapriya, J., Drouet d'Aubigny, C., Fitzgibbon, G., Jawin, E., Nolan, T., Porter, N., Rehl, M., Roper, H., Rizk, B., Tang, Y., Zeszut, Z., Gaskell, R., Palmer, E, Weirich, J., Al Asad, M., Philpott, L., Daly, M., Barnouin, O., Enos, H., \& Lauretta, D. (2020). A high-resolution global basemap of (101955) Bennu. Icarus, 113690. DOI: https://doi.org/10.1016/jicarus.2020.113690 (Accessed 16/4/2020)

10. Blake, S. (2019). University of Colorado Denver GEOG 5050: Applied Spatial Statistics. Available at: https://static1.squarespace.com/static/5c819f2e4d546e5dd8c433d2/t/5e49b8ce7a7f2c7e5e5620b3/158188974 4196/Final+Project+Report+\%281\%29.pdf (Accessed 16/4/2020)

11. Brajša-Žganec, A., Merkaš, M., \& Šverko, I. (2011). Quality of life and leisure activities: How do leisure activities contribute to subjective well-being? Social Indicators Research, 102(1), 81-91. DOI: https://doi.org/10.1007/sI 1205-010-9724-2 (Accessed 22/4/2020)

Cohen, D., McKenzie, T., Sehgal, A., Williamson, S., Golinelli, D., \& Lurie, N. (2007). Contribution of Public Parks to Physical Activity. American Journal of Public Health, 97(3), 509-514. DOI: https://dx.doi.org/10.2105/AJPH.2005.072447 (Accessed 13/3/2020)

12. Davidson, C. (2019). Dubai United Arab Emirates. Available at: https://www.britannica.com/place/DubaiUnited-Arab-Emirates/Economy\#ref342091 (Accessed 2/2/2020)

13. Davis Landscape Architecture (2014). Queen Elizabeth Olympic Park, Stratford, London Water Feature. Available at: https://www.youtube.com/watch?v=8bEXbnPs6pg (Accessed 4/6/2020)

14. Doherty, A. \& Taylor, T. (2007). Sport and physical recreation in the settlement of immigrant youth. Leisure/Loisir, 31(1), 27-55. DOI: https://doi.org/10.1080/14927713.2007.9651372 (Accessed 29/4/2020)

15. Dubai.com (2020). Dubai History. Available at: https://www.dubai.com/v/history/ (Accessed 15/1/2020)

16. Dubai Health Authority (2020). Novel Coronavirus (COVID-19). Available at: https://www.dha.gov.ae/en/Covid19/Pages/Coronavirus.aspx (Accessed 18/6/2020)

17. Dubai Municipality (2020a). About Dubai Municipality. Available at: https://www.dm.gov.ae/en/AboutDM/Pages/AboutDM.aspx (Accessed 6/2/2020) 
18. Dubai Municipality (2020b). Public Parks and Recreational Facilities. Available at: file:///C:/Users/mohda/OneDrive/Desktop/PARKS\%20INFO.pdf (Accessed 24/6/2020)

19. Dubai Statistics Center (2018). Population Bulletin Emirate of Dubai 2018. Available at: https://www.dsc.gov.ae/en-us/Themes/Pages/Population-and-Vital-Statistics.aspx?Theme=42 (Accessed 20/5/2020)

20. Dubai Statistics Center (2019a). Population by Gender - Emirate of Dubai. Available at: https://www.dsc.gov.ae/Report/DSC SYB 2019 01\%20 \%2001.pdf (Accessed 20/5/2020)

21. Dubai Statistics Center (2019b). Number of Population Estimated by Nationality- Emirate of Dubai. Available at: https://www.dsc.gov.ae/Report/DSC SYB 2019 01\%20 \%2003.pdf (Accessed 20/5/2020)

22. Elmes, A., Alemohammad, H., Avery, R., Caylor, K., Eastman, J. R., Fishgold, L., \& Lunga, D. (2020). Accounting for training data error in machine learning applied to Earth observations. Remote Sensing, 12(6), 1034. DOI: https://doi.org/10.3390/rs12061034 (Accessed 16/4/2020)

23. Emspak, J. (2018). What is Augmented Reality? Available at: https://www.livescience.com/34843-augmentedreality.html (Accessed 7/7/2020)

24. Evenson, K., Wen, F., Hiller, A, \& Cohen, D. (2013). Assessing the Contribution of Parks to Physical Activity using GPS and Accelerometry. Medicine $\mathcal{E}$ Science in Sports \& Exercise, 45(10), 1981-1987. DOI: https://dx.doi.org/10.1249\%2FMSS.0b013e318293330e (Accessed 4/1/2020)

25. Ferkins, L., Shilbury, D., \& McDonald, G. (2005). The Role of the Board in Building Strategic Capability: Towards an Integrated Model of Sport Governance Research. Sport Management Review, 8(3), 195-225. DOI: https://doi.org/10.1016/S1441-3523(05)70039-5 (Accessed 19/4/2020)

26. General Authority of Sports (2020). About Us. Available at: https://gas.gov.ae/\#/en/authority/about-us (Accessed 5/2/2020)

27. Gies, E. (2009). An Investment that Pays: The Economic Benefits of Parks and Open Space. Available at: https://conservationtools.org/library items/725-An-Investment-that-Pays-The-Economic-Benefits-ofParks-and-Open-Space (Accessed 7/6/2020)

28. Global Village (2020). Concerts. Available at: https://www.globalvillage.ae/entertainments/concerts/ (Accessed 2/2/2020)

29. Godbey, G., Caldwell, L., Floyd, M., \& Payne, L. (2005). Contributions of leisure studies and recreation and park management research to the active living agenda. American Journal of Preventive Medicine, 28(2), 150158. DOI: https://doi:10.1016/j.amepre.2004.10.027 (Accessed 4/1/2020)

30. Government of Dubai (2020). Guidelines E Protocols for Reopening. Published on April 22 $2^{\text {nd }}, 2020$, Dubai Economy.

31. Grix, J. (2010). The 'governance debate' and the study of sport policy. International journal of sport policy and politics, 2(2), 159-171. DOI: https://doi.org/10.1080/19406940.2010.488061 (Accessed 29/4/2020)

32. Janssen, I. \& LeBlanc, A. (2010). Systematic review of the health benefits of physical activity and fitness in school-aged children and youth. International journal of behavioral nutrition and physical activity, 7(1), 40. DOI: https://doi.org/10.1186/1479-5868-7-40 (Accessed 22/4/2020)

33. Jansson, M. (2013). Children's perspectives on playground use as basis for children's participation in local play space management. Local Environment, 20(2), 165-179. DOI: https://doi:10.1080/13549839.2013.857646 (Accessed 4/1/2020)

34. Jansson, M., \& Persson, B. (2010). Playground planning and management: An evaluation of standardinfluenced provision through user needs. Urban Forestry \& Urban Greening, 9(1), 33-42. DOI: https://doi:10.1016/j.ufug.2009.10.003 (Accessed 4/1/2020)

35. Joshi, N. (2019). Revolutionizing Sports With Augmented Reality. Available at: https://www.forbes.com/sites/cognitiveworld/2019/10/26/revolutionizing-sports-with-augmentedreality/\#372caa3c1416 (Accessed 7/7/2020)

36. Karim Elsayyad (2019). Dubai Creek Harbour Marina walk. Available at: https://www.youtube.com/watch?v=dWihWYxJw6c (Accessed 4/6/2020)

37. Kennelly, J. \& Watt, P. (2013). Restricting the Public in Public Space: The London 2012 Olympic Games, Hyper-Securitization and Marginalized Youth. Sociological Research Online, 18(2), 1-6. DOI: https://doi.org/10.5153\%2Fsro.3038 (Accessed 16/3/2020)

38. Lahoti, S., Kefi, M., Lahoti, A., \& Saito, O. (2019). Mapping methodology of public urban green spaces using GIS: an example of Nagpur City, India. Sustainability, 11(7), 2166. DOI: http://dx.doi.org/10.3390/su11072166 (Accessed 8/4/2020) 
39. Liszewski, A. (2019). Ikea Expands Its Augmented Reality App, Lets You Fill an Entire Room With Virtual Swedish Furniture. Available at: https://gizmodo.com/ikeas-expands-augmented-reality-app-lets-you-fill-an-e1838362429 (Accessed 7/7/2020)

40. Llorens, M. (2017). eSport Gaming: The Rise of a New Sports Practice. Sport, Ethics and Philosophy, 11(4), 464-476. DOI: https://doi.org/10.1080/17511321.2017.1318947 (Accessed 7/7/2020)

41. Lord, J. \& Stein, M. (2009). Social rights and the relational value of the rights to participate in sport, recreation, and play. Boston University International Law Journal, 27, 249-281. Available at: http://www.repositoriocdpd.net:8080/bitstream/handle/123456789/642/Art LordJE SocialRightsSport 200 9.pdf? sequence=1 (Accessed 22/4/2020)

42. Madanipour, A. (1999). Why are the design and development of public spaces significant for cities? Environment and planning B: Planning and Design, 26(6), 879-891. DOI: https://doi.org/10.1068\%2Fb260879 (Accessed 7/4/2020)

43. Mahoney, J. \& Stattin, H. (2000). Leisure activities and adolescent antisocial behavior: The role of structure and social context. Journal of adolescence, 23(2), 113-127. DOI: https://doi:10.1006/jado.2000.0302 (Accessed 22/4/2020)

44. Mataruna, L. \& Ahmed, M. (2020). Augmented reality at Dubai parks: A gaming approach to curb COVID19. The International EFA-IT BLOG. 1. 1. Availabe at: file:///C:/Users/mohda/Downloads/Paper_Blog_SportManagement_02 2020_Augument_reality.pdf (Accessed 1/8/2020)

45. Mitchell, J., Haskell, W., Snell, P., \& Van Camp, S. (2005). Task Force 8: classification of sports. Journal of the American College of Cardiology, 45(8), 1364-1367. DOI: https://doi:10.1016/j.jacc.2005.02.015 (Accessed 21/4/2020)

46. Mogg, T. (2019). IKEA's augmented reality app just got a whole lot more clever. Available at: https://www.digitaltrends.com/home/ikeas-augmented-reality-app-just-got-a-whole-lot-cleverer/ (Accessed 7/7/2020)

47. More, T. (2005). From Public to Private: Five Concepts of Park Management and Their Consequences. The George Wright Forum, 22(2), 12-20. Available at: www.jstor.org/stable/43597939 (Accessed 16/3/2020)

48. Nicholls, S. (2001). Measuring the accessibility and equity of public parks: A case study using GIS. Managing leisure, 6(4), 201-219. DOI: https://doi.org/10.1080/13606710110084651 (Accessed 7/4/2020)

49. Omar-Fauzee, M., Yusof, A., \& Zizzi, S. (2009). College students' attitude towards the utilization of the sport recreation center (SRC). European Journal of Social Sciences, 7(3), 27-40. Available at: https://www.researchgate.net/profile/Aminuddin_Yusof/publication/242083290_College_Students' Attitu de Towards the Utilization of the Sport Recreation_Center SRC/links/57201b1c08aeaced788ad46d.pdf (Accessed 28/4/2020)

50. Pacione, M (2005). Dubai. Cities, 22(3), 255-265. DOI: https://doi.org/10.1016/j.cities.2005.02.001 (Accessed 15/1/2020)

51. Papulova, Z. (2014). The Significance of Vision and Mission Development

52. for Enterprises in Slovak Republic. Journal of Economics, Business Management, 2(1), 12-16. DOI: https://doi.org/10.7763/JOEBM.2014.V2.90 (Accessed 6/2/2020).

53. Parry, J. (2019). E-sports are Not Sports. Sport, Ethics and Philosophy, 13(1), 3-18. DOI: https://doi.org/10.1080/17511321.2018.1489419 (Accessed 21/4/2020)

54. Raco, M. (2014). Delivering Flagship Projects in an Era of Regulatory Capitalism: State-led Privatization and the London Olympics 2012. International Journal of Urban and Regional Research, 38(1), 176-197. DOI: https://doi.org/10.1111/1468-2427.12025 (Accessed 7/4/2020)

55. Sherer, P. (2006). The Benefits of Parks: Why America Needs More City Parks and Open Space. Available at: https://conservationtools.org/library items/729-the-benefits-of-parks-why-america-needs-more-cityparks-and-open-space (Accessed 7/6/2020)

56. Shilbury, D., O’Boyle, I., \& Ferkins, L. (2016). Towards a research agenda in collaborative sport governance. Sport Management Review, 19(5), 479-491. DOI: https://doi.org/10.1016/j.smr.2016.04.004 (Accessed 5/2/2020)

57. Shilbury, D., Sotiriadou, K. P., \& Green, B. C. (2008). Sport development. Systems, policies and pathways: An introduction to the special issue. Sport management review, 11(3), 217-223. DOI: https://doi.org/10.1016/S1441-3523(08)70110-4 (Accessed 29/4/2020)

58. Smets, P. \& Watt, P. (2013). Exclusion and Belonging in Urban Public and Quasi-Public Space. The Open Urban Studies Journal, 6(1), 27-29. DOI: http://dx.doi.org/10.2174/1874942901306010027 (Accessed 13/3/2020) 
59. Spaaij, R. (2009). The social impact of sport: diversities, complexities and contexts. Sport in society, 12(9), 1109-1117. DOI: http://dx.doi.org/10.1080/17430430903137746 (Accessed 21/4/2020)

60. Tusznio, J., Pietrzyk-Kaszyńska, A., Rechciński, M., Olszańska, A., \& Grodzińska-Jurczak, M. (2020). Application of the ecosystem services concept at the local level-Challenges, opportunities, and limitations. Ecosystem Services, 42, 101077. DOI: https://doi.org/10.1016/j.ecoser.2020.101077 (Accessed 16/4/2020)

61. UAE Government (2019). Sports and recreation. Available at: https://www.government.ae/en/about-theuae/culture/sports-and-recreation (Accessed 21/1/2020)

62. UAE Government (2020). UAE Centennial 2071. Available at: https://www.government.ae/en/about-theuae/strategies-initiatives-and-awards/federal-governments-strategies-and-plans/uae-centennial-2071 (Accessed 6/2/2020)

63. UAE Ministry of Health \& Prevention (2020). Novel Coronavirus (COVID-19). Available at: https://www.mohap.gov.ae/en/AwarenessCenter/Pages/COVID-19.aspx (Accessed 18/6/2020)

64. Verghese, J., Lipton, R., Katz, M., Hall, C., Derby, C., Kuslansky, G., Ambrose, A., Sliwinski, M., \& Buschke, H. (2003). Leisure activities and the risk of dementia in the elderly. New England Journal of Medicine, 348(25), 2508-2516. DOI: https://doi.org/10.1056/NEJMoa022252 (Accessed 22/4/2020)

65. Visit Dubai (2020). History of Dubai. Available at: https://www.visitdubai.com/en/articles/history-of-dubai (Accessed 7/1/2020)

66. Warburton, D., Nicol, C., \& Bredin, S. (2006). Health benefits of physical activity: the evidence. CMAJ: Canadian Medical Association Journal, 174(6), 801-809. DOI: https://doi.org/10.1503/cmaj.05135 (Accessed 22/4/2020)

67. Walker, C. (2004). The Public Value of Urban Parks. Available at: https://njkeepitgreen.org/wpcontent/uploads/2018/05/Public-Value-of-Urban-Parks.pdf (Accessed 6/6/2020)

68. WHO (2020a). Coronavirus disease (COVID-19) advice for the public. Available at: https://www.who.int/emergencies/diseases/novel-coronavirus-2019/advice-for-public (Accessed $23 / 4 / 2020)$

69. WHO (2020b). Updated WHO recommendations for international traffic in relation to COVID-19 outbreak. Available at: https://www.who.int/news-room/articles-detail/updated-who-recommendations-forinternational-traffic-in-relation-to-covid-19-outbreak (Accessed 23/4/2020)

70. WHO (2020e). Coronavirus. Available at: https://www.who.int/health-topics/coronavirus\#tab=tab 1 (Accessed 18/6/2020)

71. Worldometer (2020). United Arab Emirates Population. Available at: https://www.worldometers.info/worldpopulation/united-arab-emirates-population/ (Accessed 20/5/2020)

72. Xing, Y., \& Brimblecombe, P. (2020). Urban park layout and exposure to traffic-derived air pollutants. Landscape and Urban Planning, 194, 103682. DOI: https://dx.doi.org/10.1016/j.landurbplan.2019.103682 (Accessed 16/4/2020)

73. Yeh, C. \& Taylor, T. (2011). Issues of governance in sport organisations: a question of board size, structure and roles. World Leisure Journal, 50(1), 33-45. DOI: https://doi.org/10.1080/04419057.2008.9674525 (Accessed $5 / 2 / 2020)$ 